\title{
EPIDEMIOLOGY AND OUTCOMES OF BURNS PATIENTS ADMITTED IN A DISTRICT TERTIARY CARE CENTRE, VELLORE
}

\author{
R. Soundarapandiyan ${ }^{1}$, P. Periyasamy ${ }^{2}$, V. Udhayasankar ${ }^{3}$ \\ ${ }_{1}^{1}$ Professor, Department of General Surgery, Government Vellore Medical, College, Vellore, Tamilnadu. \\ ${ }^{2}$ Assistant Professor, Department of Physiology, Government Vellore Medical College, Vellore, Tamilnadu. \\ 3Junior Resident, Department of General Surgery, Government Vellore Medical College, Vellore.
}

\section{ABSTRACT}

\section{BACKGROUND}

Burn Injuries are one of the leading causes of death in all medicolegal cases in developing countries like India. Burn Injuries are the most common mode of death in dowry deaths.

\section{MATERIALS AND METHODS}

The study was conducted as a retrospective study. The study includes all burn injury patients who got admitted in our tertiary care centre. The details were analysed.

\section{RESULTS}

Totally 1016 patients were included in this study. Among them, patients aged between 21 to 30 years and 31 to 40 years constitute the major portion of burn injury patients in both sexes. In this study, 41-50\% burns diagnosis made in maximum number of patients. Almost 89\% burns patients had varying depth of burns. Most of the burn injury occurs in home around $82 \%$. Most common nature is accidental, followed by suicidal. Most common cause of burns was due to fire. $50.19 \%$ of burns patients suffered from $>40 \%$ of burns. Most number of deaths occurred because most of them suffered $>40 \%$ of burns due to its severity.

\section{CONCLUSION}

This study helps to improve the burns safety regulations, creating awareness among the public and improve the burns care unit facilities.

\section{KEYWORDS}

Burn Injuries, Epidemiology, Outcomes, Causes.

HOW TO CITE THIS ARTICLE: Soundarapandiyan R, Periyasamy P, Udhayasankar V. Epidemiology and outcomes of burns patients admitted in a district tertiary care centre, Vellore. J. Evolution Med. Dent. Sci. 2017;6(12):918-921, DOI: 10.14260/Jemds/2017/196

\section{BACKGROUND \\ Burn injuries represents one of the major health care problems in India mostly in rural population and also in urban population. Burn injuries are also one of the most frequent injuries encountered for treatment in casualty services in our institute. The annual burn incidence in India is about 6 to 7 million per year. This is the second largest group of injuries after Road Traffic Accidents. Women are most common individuals affected in this region accounting for \\ In a developing country like India, burn injuries are still a major concern, due to lack of safety measures, absence of public awareness, dowry, poverty, illiteracy, etc. Burn injuries were also related to festival of lights in Tamilnadu (Deepavali, Karthigai Deepam) and also local festivals. Burn injuries may be accidental, suicidal, and homicidal. Epidemiological studies reveal and recognise the risk factors for burns and also planned for preventive strategies. This study tries to help in improving the medical care facilities. ${ }^{[3][4]}$} around $70 \%$. The south-east Asia region accounts for $27 \%$ of burns patients globally.

A study from Karnataka stated that incidence of burns patients was about 2300/100000 in rural areas. Even though burns mortality has decreased now a days, the burn injuries are still associated with significant morbidity and mortality.[1][2]

Financial or Other, Competing Interest: None.

Submission 13-01-2017, Peer Review 28-01-2017,

Acceptance 30-01-2017, Published 09-02-2017.

Corresponding Author:

Dr. R. Soundarapandiyan,

Professor,

Department of General Surgery,

Government Vellore Medical College,

Vellore -632011

Vellore District,

Tamilnadu.

E-mail: drrsoundar7@gmail.com

DOI: $10.14260 /$ jemds $/ 2017 / 196$

\section{MATERIALS AND METHODS}

This is a retrospective study of all burn injury patients who got admitted in our institute for the period from January 2013 to December 2015.

Burn injuries are diagnosed by the WHO's ICD classification System T20-T32. This includes injuries caused by exposure to smoke, fire and flames and also contact with heat, hot substances, exposure to electric current (X00-X19, W85-87).[5][6]

The study population is from the patients who got admitted directly to our institute and also the patients referred from our neighbouring institutes.

The patients were managed according to the burns percentage. Burns patient's hypovolemia was managed according to Parkland Formula i.e. $4 \mathrm{~mL} x$ Weight in $\mathrm{Kg} \mathrm{x}$ Percentage of Burns. The half of the Fluid Ringer Lactate should be infused within 8 hours, and next half in 16 hours, calculated from the time of occurrence of burns. From the next day onwards, the fluid requirement calculated 
depending on urine output, sweating, and normal requirements. Patients were dressed with Topical Antibiotics, Silver Sulfadiazine. Patients were treated with Intravenous Third Generation Cephalosporins, Metronidazole.[7][8]

Admitted patients' data, history were collected from the medical records of the patients, collected from medical records department. The data collected for analysis includes Age and Sex Distribution, Total Body Surface Area of burns involved, Nature of Burns, Cause and Place of accident.

\section{RESULTS}

During the period between Jan 2013 to Dec 2016, 1016 patients were admitted in our hospital.

\begin{tabular}{|c|c|c|c|}
\hline Age Group (Years) & Male (\%) & Female (\%) & Total \\
\hline$<12$ & $76(7.48)$ & $96(9.45)$ & $172(16.93)$ \\
\hline $13-20$ & $29(2.85)$ & $24(2.36)$ & $53(5.21)$ \\
\hline $21-30$ & $92(9.06)$ & $158(15.55)$ & $250(24.61)$ \\
\hline $31-40$ & $137(13.48)$ & $117(11.52)$ & $254(25)$ \\
\hline $41-50$ & $102(10.04)$ & $81(7.97)$ & $183(18.01)$ \\
\hline$>50$ & $52(5.12)$ & $52(5.12)$ & $104(10.24)$ \\
\hline Total & $488(48.03)$ & 528 (51.97) & $1016(100)$ \\
\hline
\end{tabular}

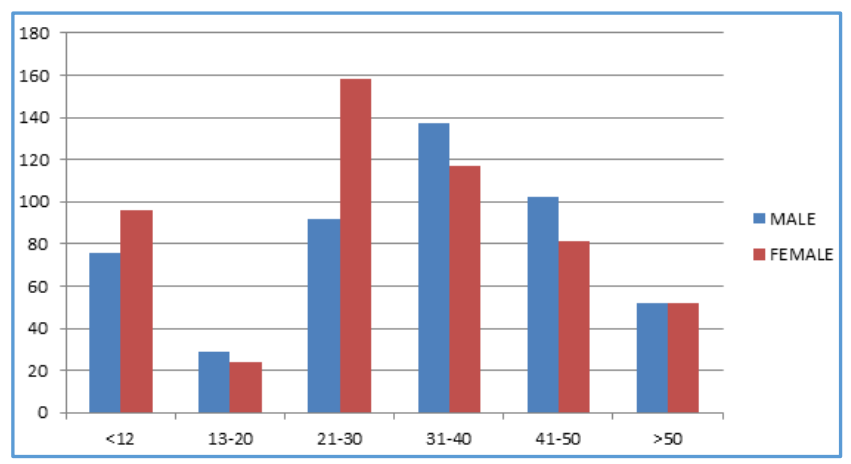

Figure 1. Age and Sex Wise Distribution of Patients

Table 1 and figure 1 depicts the age and sex distribution of burn injury patients admitted in our hospital. Among them, 21 to 30 years and 31 to 40 years constitute the major portion of burn injury patients in both sexes.

\begin{tabular}{|c|c|}
\hline \multicolumn{2}{|c|}{ Total Body Surface Area Burnt } \\
\hline TBSA (\%) & No (\%) \\
\hline $0-10$ & $96(9.45)$ \\
\hline $11-20$ & $108(10.63)$ \\
\hline $21-30$ & $147(14.47)$ \\
\hline $31-40$ & $119(11.71)$ \\
\hline $41-50$ & $213(20.96)$ \\
\hline $51-60$ & $78(7.68)$ \\
\hline $61-70$ & $61(6)$ \\
\hline $71-80$ & $72(7.09)$ \\
\hline $81-90$ & $54(5.31)$ \\
\hline $91-100$ & $68(6.7)$ \\
\hline \multicolumn{2}{|c|}{ Burn Depth } \\
\hline Superficial & $119(11.71)$ \\
\hline \multicolumn{2}{|c|}{ Place of Burn Injury } \\
\hline Home & $897(88.29)$ \\
\hline Work Place & $148(81.4)$ \\
\hline Others & $41(4.03)$ \\
\hline Table 2. Distribution of Patients according to Burn \\
\hline \multicolumn{2}{|c|}{ Characteristics } \\
\hline
\end{tabular}

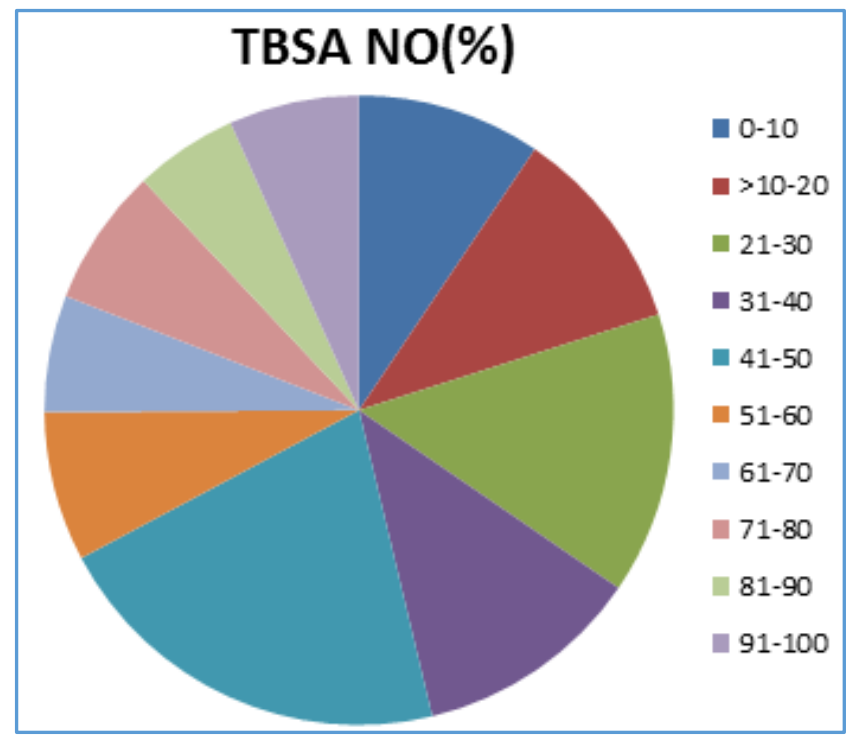

Figure 2. Burns Percentage in TBSA

Table 2 and Figure 2 depicts the Total Body Surface area involved. In this $41-50 \%$ burns diagnosis made in maximum number of patients. Almost $89 \%$ burns patients had varying depth of burns. Most of the Burn Injury occurs in home around $82 \%$.

\begin{tabular}{|c|c|c|c|c|c|}
\hline $\begin{array}{c}\text { Nature of } \\
\text { Burns }\end{array}$ & Male & Female & $\begin{array}{l}\text { Male } \\
\text { Child }\end{array}$ & $\begin{array}{c}\text { Female } \\
\text { Child }\end{array}$ & Total \\
\hline Accidental & $\begin{array}{c}282 \\
(27.76)\end{array}$ & $\begin{array}{c}155 \\
(15.26)\end{array}$ & $\begin{array}{c}76 \\
(7.48)\end{array}$ & $\begin{array}{c}96 \\
(9.45)\end{array}$ & $\begin{array}{c}609 \\
(59.95)\end{array}$ \\
\hline Suicidal & $\begin{array}{c}80 \\
(7.87) \\
\end{array}$ & $\begin{array}{c}213 \\
(20.96) \\
\end{array}$ & & & $\begin{array}{c}293 \\
(28.83) \\
\end{array}$ \\
\hline Homicidal & $6(0.59)$ & $\begin{array}{c}12 \\
(1.18)\end{array}$ & & & $\begin{array}{c}18 \\
(1.76)\end{array}$ \\
\hline Others & $\begin{array}{c}44 \\
(4.33) \\
\end{array}$ & $\begin{array}{c}52 \\
(5.13) \\
\end{array}$ & & & $\begin{array}{c}96 \\
(9.46) \\
\end{array}$ \\
\hline \multicolumn{6}{|c|}{ Causes of Burns } \\
\hline $\begin{array}{c}\text { Fire } \\
\text { Self- } \\
\text { inflicted\& } \\
\text { Stove Burst }\end{array}$ & $\begin{array}{c}362 \\
(35.63)\end{array}$ & $\begin{array}{c}366 \\
(36.02)\end{array}$ & & & $\begin{array}{c}728 \\
(71.65)\end{array}$ \\
\hline Hot liquids & & & $\begin{array}{c}74 \\
(7.28) \\
\end{array}$ & $\begin{array}{c}92 \\
(9.06) \\
\end{array}$ & $\begin{array}{c}166 \\
(16.34) \\
\end{array}$ \\
\hline $\begin{array}{c}\text { Hot } \\
\text { contacts }\end{array}$ & & & $\begin{array}{c}2 \\
(0.20) \\
\end{array}$ & $\begin{array}{c}4 \\
(0.39) \\
\end{array}$ & $\begin{array}{c}6 \\
(0.59) \\
\end{array}$ \\
\hline Flames & $\begin{array}{c}6 \\
(0.59) \\
\end{array}$ & $\begin{array}{c}8 \\
(0.79) \\
\end{array}$ & & & $\begin{array}{c}14 \\
(1.38) \\
\end{array}$ \\
\hline Others & $\begin{array}{c}44 \\
(4.33)\end{array}$ & $\begin{array}{c}58 \\
(5.71)\end{array}$ & & & $\begin{array}{c}102 \\
(10.04)\end{array}$ \\
\hline Table & thenes & Burns & 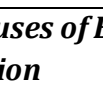 & & Vise \\
\hline
\end{tabular}

Table 3 depicts the nature of burns, most common nature is accidental, followed by suicidal. Most common cause of burns was due to fire. These are depicted in Figure $3 \mathrm{a}$ and $3 \mathrm{~b}$. 


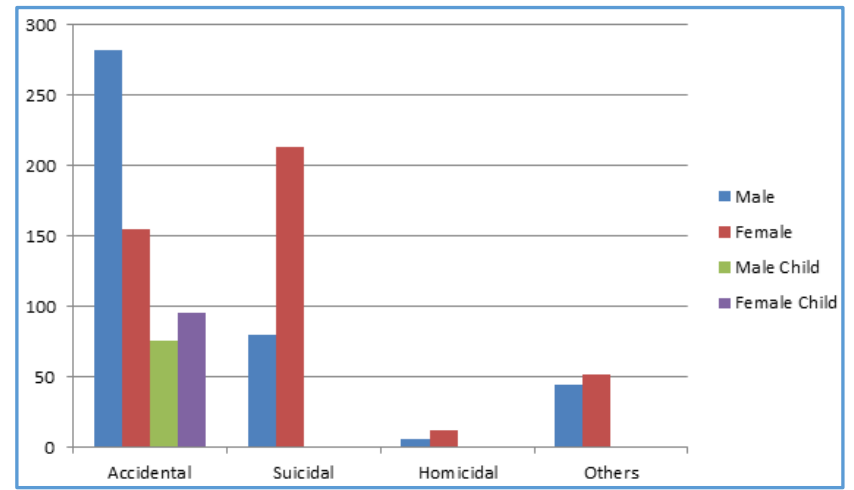

Figure 3A. Sex Wise Distribution of Nature of Burns

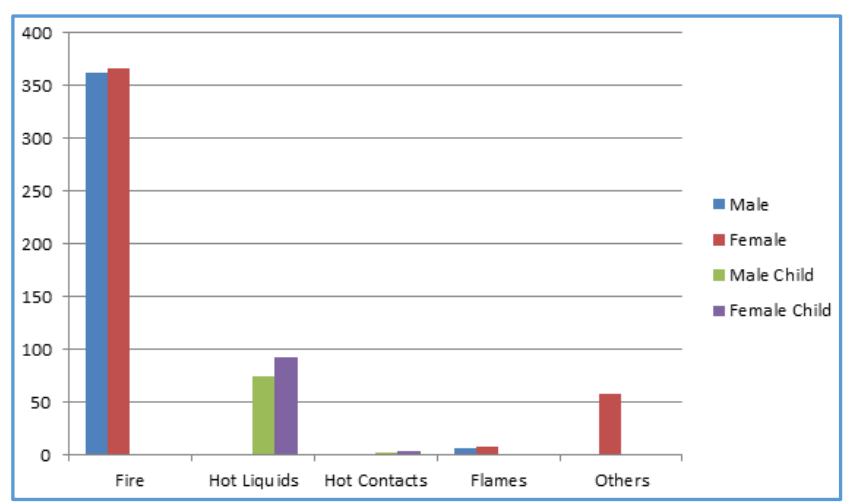

Figure 3B. Sex Wise Distribution Causes of Burns

\begin{tabular}{|c|c|c|c|}
\hline $\begin{array}{c}\text { Total Body } \\
\text { Surface Area } \\
\text { Burnt }\end{array}$ & Female & Male & Total \\
\hline$<40 \%$ & $295(29.04)$ & $211(20.77)$ & $506(49.81)$ \\
\hline$>40 \%$ & 233 (22.93) & 277 (27.26) & $510(50.19)$ \\
\hline & $528(51.97)$ & 488 (48.03) & $1016(100)$ \\
\hline
\end{tabular}

$50.19 \%$ of burns patients suffered from $>40 \%$ of burns as depicted in Table 4.

\begin{tabular}{|c|c|c|c|c|c|}
\hline Outcome & Male & Female & $\begin{array}{c}\text { Male } \\
\text { Child }\end{array}$ & $\begin{array}{c}\text { Female } \\
\text { Child }\end{array}$ & Total \\
\hline Discharged & 52 & 59 & 15 & 17 & 143 \\
$(5.13)$ & $(5.80)$ & $(1.48)$ & $(1.66)$ & $(14.07)$ \\
\hline $\begin{array}{c}\text { Discharged at } \\
\text { request }\end{array}$ & 73 & 79 & 32 & 15 & 199 \\
$(7.19)$ & $(7.78)$ & $(3.15)$ & $(1.48)$ & $(19.60)$ \\
\hline $\begin{array}{c}\text { Against Medical } \\
\text { Advice }\end{array}$ & 58 & 67 & 6 & 21 & 152 \\
$(5.71)$ & $(6.59)$ & $(0.59)$ & $(2.07)$ & $(14.96)$ \\
\hline Referral & 29 & 58 & 17 & 38 & 142 \\
$(2.85)$ & $(5.71)$ & $(1.67)$ & $(3.74)$ & $(13.97)$ \\
\hline Absconded & 12 & 27 & 6 & 5 & 50 \\
$(1.18)$ & $(2.66)$ & $(0.59)$ & $(0.49)$ & $(4.92)$ \\
\hline \multicolumn{7}{|c|}{$\begin{array}{c}\text { Death on } \\
\text { Discharge }\end{array}$} & 188 & 142 & & 330 \\
$(18.50)$ & $(13.98)$ & & $(32.48)$ \\
\hline \multicolumn{7}{|c|}{ Table 5. Outcomes of Burn Injuries } \\
\hline
\end{tabular}

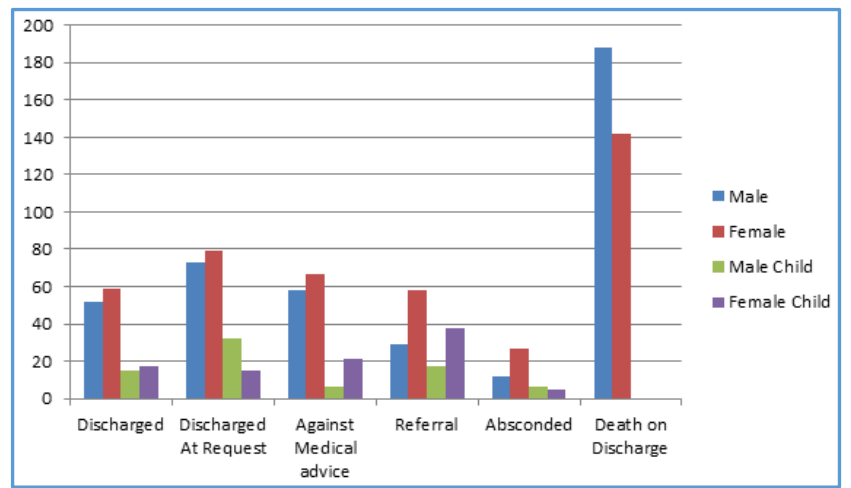

Figure 4. Outcomes of Burn Injuries

Table 5 and Figure 4 shows outcomes of burn injury patients. Most number of deaths occurred because most of them suffered $>40 \%$ of burns due to its severity.

\section{DISCUSSION}

In this study, 1016 patients from burn injuries admitted in the burns ward of department of general surgery. In this epidemiological study, the pattern of age distribution in male patients is as follows: The common age group affected was $31-40$ years (13.48\%), followed by $41-50$ years (10.04\%), 21 30 years $(9.06 \%)$, so this constitutes about $32 \%$. This constitutes major productive age group of males between 2150 years.

In female patients, the common age group affected was 21-30 years (15.55\%), followed by $31-40$ years $(11.52 \%)$, 41 50 years $(9.06 \%)$, so this constitutes about $32 \%$. This constitutes major productive age group of female patients between 21-30 years which is the common age group of marriage. These results are similar to other studies.[3],[4],[9],[10],[11],[12]

In this study, most of the burns patients suffered with total body surface area of burns involved was $41-50 \%$ burns (20.96\%), followed by $21-30 \%$ burns (14.47\%), then $31-40 \%$ burns $(11.71 \%)$. Most of the burns patients had varying depth of burns superficial to deep about 88.29\%. Only $11.71 \%$ patients had superficial burns. Most of the burns injury occurs at home $81.4 \%$ followed by work place.

In this study, most common nature of burns in all sexes was accidental (Male 27.76\%, Female 15.26\%, Male child $7.48 \%$, Female Child $9.49 \%$ ) about $59.95 \%$. Children got only accidental burn injuries according to data acquired. In females, $20.96 \%$ burn injuries occurred due to suicidal intent and also in males mostly due to quarrel in family, and some with chronic disease ailments.

Most common mode of injury in adult male and females were due to self-inflicted burns or stove burst cases which accounts for $71.65 \%$. In children, all the burns were due to hot liquids followed by hot contacts. 506 patients (49.81\%) had $<40 \%$ burns. Around 510 Patients (50.19\%) had $>40 \%$ burns which signifies severe burn injury.

Most common mode of outcome was death on discharge in both adult male (18.50\%) and female patients (13.98\%), followed by discharged at request. In children, most common of outcome in males was discharged at request followed by referral, in females it was referral followed by discharge.

The burn injuries aetiology and nature of burn injuries varies differently in the various countries. Burn injuries may be accidental, suicidal, homicidal, or due to other reasons. 
Thermal burns were the common burns; as kerosene is easily available and cheap it is most commonly used in pressure stoves leading to accidental stove bursts causing burn injuries.[13],[14]

It is more commonly seen in rural areas where kerosene stove usage was common. Majority of the burns are due to flames of kerosene stove burst and self-inflicted burns with kerosene. In developing countries, burns continue to be the endemic because of large scale use of kerosene and kerosene pressure stove.[15],[16]

Most of the times, the burn injuries are due to illiteracy, lack of awareness and safety measures for burns prevention in home. To avoid high burns cases, well-equipped burns care units should be created in all district tertiary care centres with specialists working round the clock to provide better care to the community.[17]

\section{CONCLUSION}

The burns and their complications should be prevented by educating the public on fire safety through mass media and other appropriate communication channels. Awareness, education of burns related safety practices should be imparted in home and public places. Community education about safer first aid practices such as applying cold water immediately after burns injury is very essential.

Precautions and safety measures should be taken during food preparation to prevent burns in home which is the common place of occurrence. There should be availability of good specialised burns care units with all facilities and specialists available round the clock in all districts. This study helps in improving the burn care unit facilities in all district tertiary care centres. Surveillance of burn patients helps in preventing complications like burn contractures.

\section{REFERENCES}

[1] Gururaj G, Suryanarayana SP. Burden and impact of injuries: results of population-based survey. Proceedings of the 7 th world conference on injury prevention and control, Vienna 2004:275-6.

[2] Basil A, Pruitt J, Cleon W, et al. Epidemiology of burn. In: Herendon D. Total burn care. London: WB Saunders 2002:16-7.

[3] Subrahmanyam M, Joshi AV. Analysis of burn injuries treated during one year period at a district hospital in India. Annals of burns and Fire Disasters 2003;16(2):74-6.
[4] Singh D, Singh A, Sharma AK, et al. Burn mortality in Chandigarh zone: 25 years autopsy experience from a tertiary care hospital of India. Burns 1998;24(2):150-6.

[5] Gibran NS, Wiechman S, Meyer W, et al. American Burn Association consensus statements. J Burn Care Res 2013;34(4):361-5.

[6] Jackson PC, Hardwicke J, Bamford A, et al. Revised estimates of mortality from the Birmingham burn centre, 2001-2010: a continuing analysis over 65 years. Ann Surg 2014;259(5):979-84.

[7] Egro FM, Estella CM. The need for burns teaching: a cross-sectional study to assess burns teaching in the United Kingdom. Burns 2014;40(1):173-4.

[8] Giretzlehner M, Dirnberger J, Owen $R$, et al. The determination of total burn surface area: how much difference? Burns 2013;39(6):1107-13.

[9] Peck MD. Epidemiology of burns throughout the world. Part I: distribution and risk factors. Burns 2011;37(7):1087-100.

[10] Kumar V. Accidental burn deaths in married women. The Indian Practitioner 2004;57(2):87-92.

[11] Kumar P, Chaddha A. Epidemiological study of burn cases and their mortality experiences amongst adults from a tertiary level care center. Indian Journal of Community Medicine 1997;22(4):160-7.

[12] Ahuja RB, Bhattacharya S. An analysis of 11,196 burns admissions and evaluation of conservative management techniques. Burns 2002;28(6):555-61.

[13] Bhalla S, Kale S, Mohan D. Burn properties of fabrics and garments worn in India. Accident Analysis and Prevention 2000;32(3):407-20.

[14] Batra AK. Burn mortality: recent trends and sociocultural determinants in rural India. Burns 2003;29(3):270-5.

[15] Fernandes FM, Torquato IM, Dantas MS, et al. Burn injuries in children and adolescents: clinical and epidemiological characterization. Rev Gaucha Enferm 2012;33(4):133-41.

[16] Iqbal T, Saaiq M, Ali Z. Epidemiology and outcome of burns: early experience at the country's first national burns center. Burns 2013;39(2):358-62.

[17] Grivna M, Eid HO, Abu-Zidan FM. Epidemiology of burns in the United Arab Emirates: lessons for prevention. Burns 2014;40(3):500-5. 